\title{
Intercellular Adhesion Molecule 2
}

National Cancer Institute

\section{Source}

National Cancer Institute. Intercellular Adhesion Molecule 2. NCI Thesaurus. Code C17503.

Intercellular adhesion molecule $2(275 \mathrm{aa}, \sim 31 \mathrm{kDa})$ is encoded by the human ICAM2 gene. This protein is involved in both integrin binding and the modulation of leukocyte adhesion. 